\title{
Validity and reliability of a questionnaire on knowledge of cardiovascular risk factors for use in Brazil*
}

\author{
VALIDADE E FIDEDIGNIDADE DE UM QUESTIONÁRIO DE CONHECIMENTO DE \\ FATORES DE RISCO CARDIOVASCULAR PARA USO NO BRASIL
}

\author{
VALIDEZ Y CONFIABILIDAD DEL CUESTIONARIO DE CONOCIMIENTO DE FACTORES \\ DE RIESGO CARDIOVASCULAR PARA SU USO EN EL BRASIL
}

\section{Marco Aurélio Lumertz Saffi ${ }^{1}$, Luis Joeci Jacques de Macedo Junior ${ }^{2}$, Melina Maria Trojahn ${ }^{3}$, Carisi Anne Polanczyk ${ }^{4}$, Eneida Rejane Rabelo-Silva ${ }^{5}$}

\begin{abstract}
Using a sample of patients with coronary artery disease, this methodological study aimed to conduct a cross-cultural adaptation and validation of a questionnaire on knowledge of cardiovascular risk factors (Q-FARCS), lifestyle changes, and treatment adherence for use in Brazil. The questionnaire has three scales: general knowledge of risk factors (RFs); specific knowledge of these RFs; and lifestyle changes achieved. Cross-cultural adaptation included translation, synthesis, back-translation, expert committee review, and pretesting. Face and content validity, reliability, and construct validity were measured. Cronbach's alpha for the total sample $(n=240)$ was 0.75 . Assessment of psychometric properties revealed adequate face and content validity, and the construct revealed seven components. It was concluded that the Brazilian version of Q-FARCS had adequate reliability and validity for the assessment of knowledge of cardiovascular RFs.
\end{abstract}

\section{RESUMO}

O objetivo deste estudo metodológico foi realizar adaptação transcultural e validar para uso no Brasil um questionário de conhecimento dos fatores de risco cardiovascular (Q-FARCS), mudança do estilo de vida e adesão em uma amostra de pacientes com doença arterial coronariana. O questionário é dividido em três escores: conhecimento geral dos fatores de risco; conhecimento específico e mudanças no estilo de vida. A adaptação transcultural incluiu tradução, síntese, retrotradução, análise por comitê de especialistas e pré-teste. Validade de face e conteúdo, fidedignidade e validade de constructo foram mensuradas. Na amostra total $(n=240)$ o Alpha de Cronbach foi de 0,75 . Na análise das propriedades psicométricas, a validade de face e de conteúdo mostraram-se adequadas; a de constructo indicou sete componentes. Pode-se concluir que a versão adaptada para o Brasil do QFARCS apresentou adequada fidedignidade e validade para avaliar o conhecimento dos fatores de risco cardiovascular.

\section{RESUMEN}

El objetivo de este estudio metodológico fue realizar la adaptación transcultural y validar para su uso en el Brasil, un cuestionario de conocimiento de los factores de riesgo cardiovascular (Q-FARCS), el cambio del estilo de vida y adhesión al tratamiento en una muestra de pacientes con enfermedad arterial coronaria. El cuestionario está dividido en tres scores: conocimiento general de los factores de riesgo; conocimiento específico y cambios en el estilo de vida. La adaptación transcultural incluyó traducción, síntesis, retro-traducción, análisis por comité de especialistas y pre-test. Validez de apariencia y contenido, confiabilidad y validez de constructo fueron medidas. En la muestra total $(n=240)$ el Alfa de Cronbach fue de 0,75. En el análisis de las propiedades psicométricas, la validez de apariencia y de contenido se mostraron adecuadas; la validez de constructo indicó siete componentes. Se concluye que la versión adaptada para el Brasil del Q-FARCS presentó adecuada confiabilidad y validez para evaluar el conocimiento de los factores de riesgo cardiovascular.

\author{
DESCRITORES \\ Doença das coronárias \\ Fatores de risco \\ Educação em saúde \\ Questionários \\ Estudos de validação
}

\author{
DESCRIPTORES \\ Enfermedad coronaria \\ Factores de riesgo \\ Educación en salud \\ Cuestionarios \\ Estudios de validación
}

\footnotetext{
* Taken from the dissertation "Validity and reliability of a questionnaire on knowledge of cardiovascular risk factors in patients with coronary artery disease", Federal University of Rio Grande do Sul, 2010. ${ }^{1}$ Nurse.PhD student Program in Cardiology and Cardiovascular Sciences, Federal University of Rio Grande do Sul, Brazil. marco.saffi@gmail.com ${ }^{2}$ Nurse for the School of Nursing of Federal University of Rio Grande do Sul. Porto Alegre, RS, Brazil. luis_mjr@yahoo.com.br ${ }^{3}$ Nursing School, Federal University of Rio Grande do Sul, Brazil. melina.trojahn@gmail.com ${ }^{4}$ Cardiovascular Division, Hospital de Clínicas de Porto Alegre, Brazil. cpolanczyk@hcpa.ufrgs.br ${ }^{5}$ Adjunct Professor, Nursing School, Federal University of Rio Grande do Sul, Brazil. eneidarabelo@gmail.com
} 


\section{INTRODUCTION}

Studies have found associations between various risk factors (RFs) and acute myocardial infarction ${ }^{(1-2)}$. Knowledge of patient's individual RFs can play a useful role in clinical decision-making regarding the intensity of preventive interventions and in guiding individualized management and control of these factors ${ }^{(3-4)}$. The pursuit of lifestyle changes (LCs) using health education strategies is a necessary step in reducing cardiovascular events ${ }^{(5-6)}$.

A positive correlation has been found between knowledge of RFs and adherence to LCs ${ }^{(5,7-8)}$. European investigators developed a questionnaire and administered it to patients with ischemic heart disease, and patients received guidance on LCs and pharmacotherapy. These studies reported that many patients do not receive adequate guidance on LCs and adherence to drug treatment after a cardiac event. Therefore, this knowledge is not sufficient to lead to changes in behavior concerning reduction in blood glucose levels, blood pressure levels, and smoking, or to affect adherence to drug treatment ${ }^{(7)}$. The same group of investigators published a follow-up study showing that patients' specific knowledge of their own condition correlated positively with the domains of adherence to drug treatment and LCs, stress, weight, physical activity, diet, and smoking compared with general knowledge of RFs for coronary artery disease (CAD) ${ }^{(8)}$.

There is evidence about cardiovascular RFs and health education-based prevention and control strategies ${ }^{(9-10)}$. However, there is no gold-standard instrument for the definition of patients' knowledge of the presence of these factors and their importance in CAD pathogenesis. Furthermore, it is important to stress the need for the assessment of patient adherence to guidance on LCs in order to minimize or prevent cardiovascular events.

We believe the questionnaire published by European investigators in 2004 ${ }^{(7)}$, which correlates knowledge of RFs, LC, and adherence to drug treatment, could be used in Brazilian populations after validation. Therefore, the present study sought to validate the Brazilian Portuguese version of an instrument on knowledge of cardiovascular RFs, LCs, and treatment adherence and to test its psychometric properties on a sample of CAD patients seen at an outpatient cardiology clinic.

\section{METHOD}

\section{Study design and instrument}

This was a methodological study ${ }^{(11)}$ designed to adapt and validate the instrument General and specific knowledge of risk factors for coronary heart disease, lifestyle changes, and treatment with prophylactic drugs ${ }^{(7)}$ for Brazilian

populations. The study was conducted at the specialized outpatient Ischemic Heart Disease clinic of a university hospital in the state of Rio Grande do Sul. Data were collected between March 2008 and December 2009.

The instrument validated in this study consisted of 28 items designed to assess general knowledge of cardiovascular RFs (obesity, cholesterol and glucose levels, physical activity, stress, smoking, dietary habits, heredity, and blood pressure) in direct relation to CAD progression (Score 1); specific knowledge of these RFs, except heredity, in direct relation to the patient's own CAD (Score 2); and LCs after the event. LCs were defined after scoring changes made toward weight loss, cholesterol and glucose reduction, increased frequency of physical exercise, reduction in stress levels and smoking habits, dietary changes, and decreased blood pressure levels (Score 3). Adherence to pharmacotherapy was measured using scores concerning drugs used in the management of dyslipidemia, diabetes, and hypertension. A scale of 0-9 was used, with higher scores indicating greater perceived importance of RFs for CAD. Lower scores indicated that patients perceived factors as being less important.

Knowledge of patient's individual risk factors can play a useful role in clinical decisionmaking regarding the intensity of preventive interventions and in guiding individualized management and control of these factors.

\section{Cross-cultural adaptation and validation}

Cross-cultural adaptation and validation were conducted after obtaining permission from the authors of the original instrument. The process comprised translation, synthesis of translations, back-translation, expert committee review, pretesting, and analysis of psychometric properties $^{(12-13)}$

The instrument was translated by two professionals with complete mastery of the source and target languages. The translators then discussed their Portuguese versions of the instrument and developed a consensus translation. Using this preliminary version of the instrument, both translators met the lead investigator and developed a synthesis draft of the instrument. This synthesis version was forwarded to two others translators who back-translated it into the source language of the original instrument. The back-translation stage enabled identification of potential errors in interpretation and flaws in cross-cultural adaptation that might compromise or alter the meaning of questionnaire items ${ }^{(12)}$. A committee of experts (bilingual health care providers and professionals familiar with this methodology) then checked the instrument for semantic, idiomatic, experimental, and conceptual equivalence ${ }^{(12-14)}$ and defined a version to be used in pretesting. The pretesting stage, conducted on a sample of 40 patients, assessed the extent to which respondents understood the questionnaire items ${ }^{(12)}$.

After pretesting, the psychometric properties of the final adapted version were assessed for determining
Validity and reliability of the questionnaire of knowledge of cardiovascular risk factors for use in Brazil Saffi MAL, Macedo Junior LJJ, Trojahn MM, Polanczyk CA, Rabelo-Silva ER 
whether the characteristics of the original instrument were retained. To assess the item homogeneity of the instrument, reliability was measured with Cronbach's alpha. Cronbach's alpha values ranged from 0 to 1 according to the correlations between the items. Values above 0.70 are considered acceptable ${ }^{(15)}$.

The validity of the instrument was established by the measurement of face and content validity. Face validity measured the understanding and acceptance of questionnaire items by investigators and respondents, whereas content validity, evaluated by the expert committee, reflected the relevance of each questionnaire item. Construct validity was assessed using exploratory factor analysis with principal component analysis (PCA).

After cross-cultural adaptation and validation, the resulting questionnaire was given the Portuguese title Questionário de Fatores de Risco Cardiovascular (Q-FARCS, Cardiovascular Risk Factors Questionnaire).

\section{Study population, data collection, and ethical aspects}

The instrument was administered to patients with a diagnosis of CAD, of both genders, all above 18 years, and selected by convenience sampling. The lead investigator and two other previously trained examiners administered the final version of the instrument to this target population. On average, administration of the questionnaire took $20 \mathrm{~min}$. Patients with neurological sequelae, which might lead to a compromise of the understanding of the questionnaire items, were excluded from the sample.

When items were not applicable to a given participant, the corresponding answers were recorded as missing data. Sociodemographic and clinical data were collected from patient charts. All patients provided written informed consent prior to participation in the study. This project was approved by the relevant institutional review board (judgment no. 06/570).

\section{Data analysis}

Statistical analyses were performed using Statistical Package for the Social Sciences 18.0 software. Continuous variables were expressed as mean \pm standard deviation or median (interquartile range) as appropriate according to the distribution of data. Cronbach's alpha was used to assess internal consistency. Bartlett's test and the Kaiser-Meyer-Olkin (KMO) criterion were used to determine whether PCA was applicable. A rotated component matrix (Varimax rotation) was computed to determine which factors were formed.

The sample size was set at 240 patients. According to the literature, the number of observations must be at least five times the number of variables for analysis ${ }^{(16)}$. In this study, the questionnaire on which PCA was performed consisted of 23 items.

\section{RESULTS}

\section{Translation and cross-cultural adaptation}

There was no need to modify any terms or expressions for cross-cultural adaptation. The expert committee only identified a need for the inclusion of an additional item concerning patients' knowledge of the cardiovascular RFs associated with CAD: Do you know the risk factors that lead to the progression of coronary artery disease? The final instrument consisted of 29 items. This question (item 1) was used only to identify RFs that the patients were most familiar with; it was not included in analyses.

The experts' committee (bilingual professionals of the health care area and experts on methodology) conferred semantic, idiomatic, functional, and conceptual equivalence to the tool, even as face and content validity.

\section{Questionnaire administration}

The questionnaire was administered to a sample of 240 patients. Mean age was $65 \pm 10$ years; 135 (56\%) patients were male and $50 \%$ had 5 years of formal education or less. Regarding comorbidities, hypertension and dyslipidemia were present in $100 \%$ and $96 \%$ of the patients, respectively. Other characteristics are shown in Table 1.

Table 1 - Demographic and clinical profile of patients with coronary heart disease - Porto Alegre, RS, Brazil, 2009.

\begin{tabular}{lc}
\hline Characteristics & $\mathbf{n = 2 4 0}$ \\
\hline Age (years) ${ }^{*}$ & $65 \pm 10$ \\
Gender (male) ${ }^{\dagger}$ & $135(56)$ \\
Years of formal education $^{\ddagger}$ & $5(4-8)$ \\
Comorbidities and risk factors ${ }^{\dagger}$ & \\
Hypertension & $240(100)$ \\
Dyslipidemia & $230(96)$ \\
Acute myocardial infarction & $135(56)$ \\
Smoking (former) & $122(51)$ \\
Diabetes mellitus & $118(49)$ \\
Percutaneous coronary intervention & $117(48)$ \\
Coronary artery bypass surgery & $84(35)$ \\
Family history & $39(16)$ \\
Smoking (current) & $31(13)$ \\
Obesity & $30(12)$ \\
Stroke & $17(7)$ \\
\hline Variable expressed as mean \pm standard deviation; $\dagger$ Categorical data \\
expressed as $n$ (\%); $\ddagger$ Variable expressed as median (interquartile range)
\end{tabular}

Table 2 shows the internal consistency of the questionnaire for the sample of 240 patients. After analysis of all items, 69 valid instruments remained, with Cronbach's alpha of 0.75 . The 171 remaining instruments had missing data for at least one of the items designed to assess adherence to drug treatment (items 27, 28, and 29: Do you take prescribed lipid-lowering drugs?; Do you take prescribed antidiabetic medication; and Do you take prescribed blood pressure-lowering drugs?), respectively, or for item 24 (Have you changed your smoking habits after your coronary heart disease and/or your heart operation?). 
Table 2 - Internal consistency values and overall scores of the total sample - Porto Alegre, RS, Brazil, 2009

\begin{tabular}{|c|c|c|c|}
\hline Patients $(n=240)$ & Items & $\begin{array}{c}\text { Valid } \\
\text { Instruments }\end{array}$ & $\begin{array}{l}\text { Cronbach's } \\
\text { alpha }\end{array}$ \\
\hline \multicolumn{4}{|l|}{$\begin{array}{l}\text { Overall internal } \\
\text { consistency }\end{array}$} \\
\hline 240 & 28 & 69 & 0.75 \\
\hline 240 & $25^{*}$ & 153 & 0.81 \\
\hline 240 & $24^{\dagger}$ & 240 & 0.78 \\
\hline \multicolumn{4}{|c|}{$\begin{array}{l}\text { Score-specific internal } \\
\text { consistency }\end{array}$} \\
\hline Score 1 (9 items) & 09 & 240 & 0.71 \\
\hline Score 2 ( 8 items) & 08 & 240 & 0.62 \\
\hline Score 2 (7 items) & $07^{\star}$ & 240 & 0.70 \\
\hline Score 3 ( 8 items) & 08 & 153 & 0.73 \\
\hline Score 3 (7 items) & $07^{\S}$ & 240 & 0.77 \\
\hline
\end{tabular}

When internal consistency was evaluated after exclusion of the three items concerning adherence to drug treatment (items 27, 28, and 29), 153 instruments were analyzed, with Cronbach's alpha of 0.81 . Analysis was also performed after exclusion of the three adherence-related items (items 27, 28, and 29) as well as item 24. In this case, all 240 instruments were valid and Cronbach's alpha was 0.78 .

After stratification by score, the results of internal consistency analysis were as follows: Score 1 (nine ite$\mathrm{ms}$ regarding general knowledge of cardiovascular RFs, items 2-10) had Cronbach's alpha of 0.71, with all 240 instruments included in the analysis; Score 2 (eight items regarding specific knowledge of cardiovascular RFs, items 11-18) had Cronbach's alpha of 0.62, with all 240 instruments included in the analysis. However, isolated analysis of Cronbach's alpha for item 16 (alpha $=0.69$ ) influenced the reduced overall alpha for Score 2. Therefore, we excluded this item ("Do you think smoking habits influence or have influenced your coronary heart disease?") and repeated the analysis. In this case, Cronbach's alpha for Score 2 was 0.70. Score 3 (eight items regarding LCs, items 19-26) had an alpha of 0.73 , with 153 instruments included in the analysis. However, after exclusion of item 24 from the analysis because of missing data in 87 instruments, Cronbach's alpha for this score increased to 0.77 .

Tables 3 and 4 show overall Cronbach's alpha values, item-total correlation coefficients (correlation between each item in the domain and its total score), and alpha values when each item was excluded.

Cronbach's alpha for the items designed to assess general knowledge of cardiovascular RFs (Score 1: ite$\mathrm{ms} 2$ to 10 ) was 0.71 . With exclusion of each item individually, Cronbach's alpha ranged from 0.67 to 0.70 . The lowest internal consistency was observed for the items that assess specific knowledge of cardiovascular
RFs (Score 2: items 11-18), with Cronbach's alpha of 0.62 . When each of these items was excluded individually, Cronbach's alpha ranged from 0.53 to 0.69 . These values are shown in Table 3.

Table 3 - Overall Cronbach's alpha for Scores 1 and 2, item-total correlation coefficients, and Cronbach's alpha when each item excluded - Porto Alegre, RS, Brazil, 2009

\begin{tabular}{|c|c|c|}
\hline Items & $\begin{array}{l}\text { Item-total } \\
\text { correlation }\end{array}$ & $\begin{array}{l}\text { Cronbach's alpha } \\
\text { if item excluded }\end{array}$ \\
\hline \multicolumn{3}{|l|}{ Score $1($ overall alpha $=\mathbf{0 . 7 1})$} \\
\hline $\begin{array}{l}\text { 2. Do you think obesity influences } \\
\text { the progress of coronary heart dis- } \\
\text { ease? }\end{array}$ & 0.33 & 0.70 \\
\hline $\begin{array}{l}\text { 3. Do you think high lipid levels } \\
\text { influence the progress of coronary } \\
\text { heart disease? }\end{array}$ & 0.50 & 0.67 \\
\hline $\begin{array}{l}\text { 4. Do you think high blood glucose } \\
\text { levels/diabetes influence the progress } \\
\text { of coronary heart disease? }\end{array}$ & 0.40 & 0.68 \\
\hline $\begin{array}{l}\text { 5. Do you think exercise habits influ- } \\
\text { ence the progress of coronary heart } \\
\text { disease? }\end{array}$ & 0.44 & 0.67 \\
\hline $\begin{array}{l}\text { 6. Do you think stress influences the } \\
\text { progress of coronary heart disease? }\end{array}$ & 0.33 & 0.70 \\
\hline $\begin{array}{l}\text { 7. Do you think smoking habits } \\
\text { influence the progress of coronary } \\
\text { heart disease? }\end{array}$ & 0.46 & 0.68 \\
\hline $\begin{array}{l}\text { 8. Do you think diet influences the } \\
\text { progress of coronary heart disease? }\end{array}$ & 0.43 & 0.68 \\
\hline $\begin{array}{l}\text { 9. Do you think hereditary influ- } \\
\text { ences the progress of coronary heart } \\
\text { disease? }\end{array}$ & 0.38 & 0.69 \\
\hline $\begin{array}{l}\text { 10. Do you think high blood pressure } \\
\text { influences the progress of coronary } \\
\text { heart disease? }\end{array}$ & 0.33 & 0.70 \\
\hline \multicolumn{3}{|l|}{ Score 2 (overall alpha $=\mathbf{0 . 6 2}$ ) } \\
\hline $\begin{array}{l}\text { 11. Do you think obesity influences } \\
\text { or has influenced the progress of your } \\
\text { coronary heart disease? }\end{array}$ & 0.50 & 0.53 \\
\hline $\begin{array}{l}\text { 12. Do you think high lipid levels } \\
\text { influence or have influenced your } \\
\text { coronary heart disease? }\end{array}$ & 0.43 & 0.57 \\
\hline $\begin{array}{l}\text { 13. Do you think high blood glucose } \\
\text { levels/diabetes influence or have in- } \\
\text { fluenced your coronary heart disease? }\end{array}$ & 0.43 & 0.56 \\
\hline $\begin{array}{l}\text { 14. Do you think exercise habits influ- } \\
\text { ence or have influenced your coronary } \\
\text { heart disease? }\end{array}$ & 0.46 & 0.55 \\
\hline $\begin{array}{l}\text { 15. Do you think stress influences or } \\
\text { has influenced your coronary heart } \\
\text { disease? }\end{array}$ & 0.10 & 0.64 \\
\hline $\begin{array}{l}\text { 16. Do you think smoking habits influ- } \\
\text { ence or have influenced your coronary } \\
\text { heart disease? }\end{array}$ & 0.03 & 0.69 \\
\hline $\begin{array}{l}\text { 17. Do you think diet influences or } \\
\text { has influenced your coronary heart } \\
\text { disease? }\end{array}$ & 0.41 & 0.57 \\
\hline $\begin{array}{l}\text { 18. Do you think high blood pressure } \\
\text { influences or has influenced your cor- } \\
\text { onary heart disease? }\end{array}$ & 0.33 & 0.59 \\
\hline
\end{tabular}

Validity and reliability of the questionnaire of knowledge of cardiovascular risk factors for use in Brazil Saffi MAL, Macedo Junior LJJ, Trojahn MM, Polanczyk CA, Rabelo-Silva ER 
Table 4 shows that Cronbach's alpha for the LC items (Score 3: items 19-26) was 0.73. When each of these items was excluded individually, Cronbach's alpha ranged from 0.66 to 0.75 . For the three items that assessed adherence to drug treatment (items 27, 28, and 29), Cronbach's alpha was 0.20 .

Table 4 - Overall Cronbach's alpha for Score 3, item-total correlation coefficients, and Cronbach's alpha when each item was excluded - Porto Alegre, RS, Brazil, 2009

Items $\begin{gathered}\text { Item-total } \\ \text { correlation }\end{gathered}$ Cronbach's alpha

Score 3 (overall alpha $=\mathbf{0 . 7 3}$ )

19. Have you lost weight with

0.49

lifestyle changes after your coronary heart disease and/or after your coronary heart operation?

20. Have you reduced your lipid levels with lifestyle changes after your coronary heart disease and/or your coronary heart operation?

21. Have you reduced your blood glucose levels/diabetes with lifestyle changes after your coronary heart disease and/or your heart operation?

22. Have you increased your exercise habits after your coronary heart disease and/or your coronary heart operation?

23. Have you reduced your stress level with lifestyle changes after your coronary heart disease and/or your coronary heart operation?

24. Have you changed your smoking habits after your coronary heart disease and/or your heart operation?

25 . Have you made any dietary changes after your coronary heart disease and/or your heart operation?

26. Have you reduced your blood pressure level with lifestyle changes after your coronary heart disease and/or your coronary heart operation?

\section{Construct validity}

Items 24, 27, 28, and 29 of the questionnaire were excluded from PCA due to missing data. After initial analysis with the Varimax method, item 16 was found to constitute an isolated component and was thus removed from subsequent analyses. Items 15 and 23 of the questionnaire showed weak item-total correlation (<0.30). However, after analysis with the Varimax method these items formed component 5, comprising three items that have shown the a relationship between stress and cardiovascular disease. Therefore, 23 items were assessed. After exploratory PCA, the KMO value was 0.776 and Bartlett's test was statistically significant $(p<0.001)$. We found that $59.6 \%$ of the variability in the 23 analyzed items was explained by variation in the seven artificial components generated by PCA. Component 1 comprised items $11-14$ and 17; component 2 items 19-22 and 25; component 3 items 8, 10, and 3 ; component 4 items 7, 9, and 4; component 5 items 15, 6, and 23; component 6 items 2 and 5; and component 7 items 26 and 18 (Table 5).

\section{DISCUSSION}

This was the first Brazilian study to conduct a cross-cultural adaptation and validation of a questionnaire about knowledge of cardiovascular RFs, LCs, and adherence to drug treatment in CAD patients. The validation process was conducted on the basis of systematic methodological properties in the pursuit of equivalence between the original instrument and the adapted version ${ }^{(12)}$. Results showed that the adapted instrument was validated for use in Brazilian CAD patients.

With regard to reliability, the adapted version of the questionnaire had Cronbach's alpha of 0.75 . In the original study, Cronbach's alpha was 0.73 , which shows the similarity of the results obtained and demonstrates item homogeneity ${ }^{(7)}$.

A study published in 2010 validated an instrument in a sample of patients who were taking part in a cardiac rehabilitation program. The instrument items measured several domains, but only seven were related to knowledge of cardiovascular RFs. In that study, Cronbach's alpha was $0.64^{(17)}$. Following the same research track as their prior study, the same group of investigators constructed and validated an instrument to assess knowledge of CAD patients for patient education purposes. Of the 19 items, only seven were associated with knowledge of cardiovascular RFs. In this study, Cronbach's alpha and the intraclass correlation coefficient were 0.68 and 0.78 , respectively ${ }^{(18)}$. In our study, Cronbach's alpha for the items that assessed adherence to drug treatment was 0.20 . Some studies that used eight- ${ }^{(19)}$ or sevenitem $^{(20)}$ measures of adherence obtained Cronbach's alpha values of 0.54 and 0.60 , respectively, which suggests that other instruments also failed to exhibit internal consistency for adherence-related items.

On exploratory PCA, the variability of the 23 analyzed items led to the formation of seven artificial components. We can suggest a new grouping and distribution of items in this validated instrument for use in future studies, as follows. Items were grouped coherently, enabling an assessment that is more specifically directed at knowledge of RFs. Component 1 consisted of five items regarding general knowledge of RFs, such as obesity, blood glucose and lipid levels, diet, and physical exercise. Component 2 consisted of five items regarding lifestyle changes after a cardiovascular event, such 
Table 5 -Variability in the 23 items analyzed using a rotated component matrix (Varimax rotation) - Porto Alegre, RS,

Brazil, 2009

\begin{tabular}{|c|c|c|c|c|c|c|c|}
\hline \multirow[t]{2}{*}{ Item } & \multicolumn{7}{|c|}{ Component } \\
\hline & 1 & 2 & 3 & 4 & 5 & 6 & 7 \\
\hline Q 11 & 0.815 & 0.082 & 0.088 & 0.069 & -0.064 & 0.103 & -0.058 \\
\hline Q 13 & 0.656 & 0.107 & 0.021 & 0.297 & -0.146 & -0.039 & 0.080 \\
\hline Q 12 & 0.632 & 0.156 & 0.232 & -0.265 & 0.082 & 0.081 & 0.203 \\
\hline Q 17 & 0.572 & 0.128 & 0.020 & 0.072 & 0.067 & 0.029 & 0.203 \\
\hline Q 14 & 0.522 & 0.071 & -0.163 & 0.372 & 0.142 & 0.280 & 0.126 \\
\hline Q 25 & 0.058 & 0.806 & 0.026 & 0.024 & -0.018 & 0.154 & 0.111 \\
\hline Q 20 & 0.144 & 0.764 & 0.142 & -0.049 & -0.074 & 0.077 & 0.178 \\
\hline Q 21 & 0.390 & 0.565 & -0.004 & 0.192 & -0.189 & 0.122 & 0.117 \\
\hline Q 22 & 0.142 & 0.524 & -0.129 & 0.209 & 0.117 & -0.290 & -0.003 \\
\hline Q 19 & 0.494 & 0.514 & 0.124 & -0.103 & 0.107 & -0.070 & 0.004 \\
\hline Q 8 & 0.146 & -0.067 & 0.711 & 0.123 & -0.011 & 0.256 & 0.022 \\
\hline Q 10 & 0.010 & 0.106 & 0.696 & 0.108 & 0.125 & -0.098 & 0.327 \\
\hline Q 3 & 0.063 & 0.101 & 0.664 & 0.208 & 0.179 & 0.132 & -0.287 \\
\hline Q 7 & -0.042 & -0.012 & 0.219 & 0.668 & -0.017 & 0.295 & 0.265 \\
\hline Q 9 & 0.150 & 0.017 & 0.144 & 0.618 & 0.364 & -0.085 & -0.021 \\
\hline Q 4 & 0.195 & 0.116 & 0.321 & 0.596 & -0.067 & 0.094 & -0.310 \\
\hline Q 15 & 0.055 & -0.087 & 0.067 & 0.076 & 0.850 & -0.009 & -0.045 \\
\hline Q 6 & -0.079 & -0.015 & 0.127 & 0.123 & 0.660 & 0.336 & 0.043 \\
\hline Q 23 & -0.025 & 0.466 & 0.014 & -0.088 & 0.474 & 0.000 & 0.004 \\
\hline Q 2 & 0.091 & 0.060 & 0.096 & 0.020 & 0.050 & 0.807 & -0.081 \\
\hline Q 5 & 0.156 & 0.081 & 0.159 & 0.263 & 0.251 & 0.541 & 0.151 \\
\hline Q 26 & 0.137 & 0.295 & -0.041 & 0.139 & -0.119 & 0.039 & 0.676 \\
\hline Q 18 & 0.393 & 0.088 & 0.121 & -0.114 & 0.111 & -0.008 & 0.673 \\
\hline
\end{tabular}

as changes in dietary habits, lipid and glucose levels, engagement in physical activity, and weight. Components 3 and 4, which comprised three items each, grouped patients' specific knowledge of cardiovascular disease. Component 5 comprised three items regarding the relationship between stress and cardiovascular disease. Component 6 consisted of two items regarding general knowledge of RFs such as obesity and physical exercise. Lastly, component 7 comprised two items regarding the relationship between blood pressure and cardiovascular disease.

Cardiovascular RFs and strategies for their prevention and control through health education have been well established and are evidence-based. However, prior to the implementation of any approach meant to reduce or eliminate these factors, it is important to determine the extent of patients' knowledge of these factors, as well as their potential for adherence to the guidance that will be provided.

\section{Study's limitations}

The shortage of validation studies of instruments that addressed all of cardiovascular risk factors, thus with analyzes of reliability and validity have limited the discussion of this study.

\section{CONCLUSION}

The results show that this questionnaire was successfully adapted and validated for use in Brazilian CAD patients. This instrument can support the individualized management of CAD patients and thus contribute to a comprehensive health education process.

Further studies are required for a better understanding of the relationship between knowledge of cardiovascular FRs, LCs, and their contributions to reduction in cardiovascular events in clinical practice. Future studies using other measures of adherence are warranted.

This paper provides the scientific community with an instrument that covers aspects of patients' knowledge of cardiovascular RFs and can serve as a basis for the assessment of the effectiveness of interventions used in clinical practice. This instrument proved to be a valid indicator for the measurement of these issues. The adapted and validated Brazilian version of this instrument, known as Q-FARCS, consists of several components that are subdivided into scores for the quantification of patients' knowledge of cardiovascular RFs.

$\begin{array}{rrr}\text { Rev Esc Enferm USP } \\ 2013 ; 47(5): 1083-9 & \text { Validity and reliability of the questionnaire of knowledge } \\ \text { of cardiovascular risk factors for use in Brazil } & \text { Saffi MAL, Macedo Junior LJJ, Trojahn MM, Polanczyk CA, Rabelo-Silva ER }\end{array}$




\section{REFERENCES}

1. Piegas LS, Avezum A, Pereira JC, Neto JM, Hoepfner C, Farran $\mathrm{JA}$, et al. Risk factors for myocardial infarction in Brazil. Am Heart J. 2003;146(2):331-8.

2. Gus I, Fischmann A, Medina C. Prevalence of risk factors for coronary artery disease in the Brazilian State of Rio Grande do Sul. Arq Bras Cardiol. 2002;78(5):478-90.

3. World Health Organization. Integrated management of cardiovascular risk: report of a WHO Meeting [Internet]. Geneva: WHO; 2002 [cited 2012 Mar 22]. Available from: http://whqlibdoc.who.int/publications/9241562242.pdf

4. Yusuf S, Hawken S, Ounpuu S, Dans T, Avezum A, Lanas F, et al.; INTERHEART Study Investigators. Effect of potentially modifiable risk factors associated with myocardial infarction in 52 countries (the INTERHEART study): case-control study. Lancet. 2004;364(9438):937-52.

5. Maruthur NM, Wang NY, Appel LJ. Lifestyle interventions reduce coronary heart disease risk: results from the PREMIER trial. Circulation. 2009;119(15):2026-31.

6. Rabelo E, Aliti G, Domingues F, Assis MCS, Saffi MA, Linhares $J C$, et al. Enfermagem em cardiologia baseada em evidência. Rev HCPA. 2007;27(2):43-8.

7. Alm-Roijer C, Stagmo M, Udén G, Erhardt L. Better knowledge improves adherence to lifestyle changes and medication in patients with coronary heart disease. Eur J Cardiovasc Nurs. 2004;3(4):321-30.

8. Alm-Roijer C, Fridlund B, Stagmo M, Erhardt L. Knowing your risk factors for coronary heart disease improves adherence to advice on lifestyle changes and medication. J Cardiovasc Nurs. 2006;21(5):E24-31.

9. Allen JK, Dennison CR. Randomized trials of nursing interventions for secondary prevention in patients with coronary artery disease and heart failure: systematic review. J Cardiovasc Nurs. 2010;25(3):207-20.

10. Silva AL. Nursing in the era of globalisation: challenges for the 21st century. Rev Latino Am Enferm. 2008;16(4):787-90.
11. Wood G, Haber J. Pesquisa em enfermagem: métodos, avaliação, crítica e utilização. Rio de Janeiro: Guanabara Koogan; 2001.

12. Beaton DE, Bombardier C, Guillemin F, Ferraz MB. Guidelines for the process of cross-cultural adaptation of self-report measures. Spine (Phila Pa 1976). 2000;25(24):3186-91.

13. Surgeons Avansi PoA, Meneghin P. Translation and adaptation of the In-Hospital Utstein style into the Portuguese language. Rev Esc Enferm USP. 2008;42(3):504-11.

14. Beaton D, Bombardier C, Guillemim F, Ferraz M. Recommendations for the cross- cultural adaptation of the health status measures [Internet]. Rosemont: American Academy of Ortopaedic Surgeons/Institute for Work \& Health; 2002 [cited 2012 Mar 24]. Available from: http://med.umn.edu/ortho/prod/ groups/med/@pub/@med/@ortho/documents/asset/med_ asset_360072.pdf

15. Streiner DL. Starting at the beginning: an introduction to coefficient alpha and internal consistency. J Pers Assess. 2003;80(1):99-103.

16. Sapnas KG, Zeller RA. Minimizing sample size when using exploratory factor analysis for measurement. J Nurs Meas. 2002;10(2):135-54.

17. Ghisi GL, Leite CM, Durieux A, Schenkel Ide C, Assumpção MS, Barros MM, et al. Validation into portuguese of the Maugerl CaRdiac preventiOn-Questionnaire (MICRO-Q). Arq Bras Cardiol. 2010;94(3):372-8, 94-400.

18. Ghisi GL, Durieux A, Manfroi WC, Herdy AH, Carvalho TD, Andrade $A$, et al. Construction and validation of the CADE-Q for patient education in cardiac rehabilitation programs. Arq Bras Cardiol. 2010;94(6):813-22.

19. Korb-Savoldelli V, Gillaizeau F, Pouchot J, Lenain E, Postel-Vinay $\mathrm{N}$, Plouin PF, et al. Validation of a French Version of the 8-Item Morisky Medication Adherence Scale in Hypertensive Adults. J Clin Hypertens (Greenwich). 2012;14(7):429-34.

20. Silva Carvalho AR, Dantas RA, Pelegrino FM, Corbi IS. Adaptation and validation of an oral anticoagulation measurement of treatment adherence instrument. Rev Latino Am Enferm. 2010;18(3):301-8.

\section{Acknowledgements}

We would like to thank Carin Alm-Roijer and the other authors of the original instrument for authorizing our adaptation and validation of this questionnaire for use in Brazil.

Financial support: Incentive Research Fund and Events Hospital de Clínicas de Porto Alegre. 